\title{
Parental economic hardship and children's achievement orientations
}

Jeylan T. Mortimer - University of Minnesota

morti002@umn.edu

Lei Zhang - University of Minnesota

Jeanette Hussemann - Urban Institute, Washington DC

Chen-Yu Wu - University of Minnesota

(Received September 2013 Revised February 2014)

http://dx.doi.org/10.14301/llcs.v5i2.271

\section{Abstract}

While children's orientations to achievement are strong predictors of attainments, little is known about how parental economic hardship during recessionary times influences children's orientations to their futures. The Youth Development Study has followed a community sample of young people in St Paul, Minnesota, from mid-adolescence through their mid-thirties with near-annual surveys, and has recently begun surveying the children of this cohort. Using linked parent and child data, the present study examines the relationship between parental economic hardship and children's achievement orientations in the aftermath of the recent "Great Recession." Initial OLS analyses draw on 345 parent-child pairs, with data collected from parents during their adolescence, during the decade prior to the recession, and in 2011, and from their children (age 11 and older) in 2011. Then, first difference models are estimated, based on a smaller sample $(N=186)$ of parents and children who completed surveys in both 2009 and 2011. Our findings indicate that when families are more vulnerable, as a result of low parental education and prior parental unemployment experience, children's achievement orientations are more strongly threatened by the family's economic circumstances. For example, as parental financial problems increased, economic expectations declined only among children of the least well-educated parents. Low household incomes diminished educational aspirations only when parents experienced unemployment during the ten years prior to the recent recession. Parental achievement orientations, as adolescents, were also found to moderate the impacts of shifts in the family's economic circumstances. Finally, boys reacted more strongly to their parents' hardship than girls.

Keywords: economic hardship, Great Recession, parental unemployment, economic expectations, educational aspirations, adolescent vocational development

\section{Introduction}

Parents' fortunes rise and fall, especially in turbulent economic times. With income losses and uncertainty in income flows, and mounting financial stressors, children may observe their parents struggling to make ends meet to preserve a threatened standard of living. This research examines the linkages between key indicators of parental economic well-being and children's achievement orientations, in a community sample surveyed in 2009 and 2011. The recent recession in the United States that began in December 2007 produced high unemployment rates, hovering around 9 to 10 
percent, and median household income decreased by 10 percent. Although the recession was officially over in June 2009 (National Bureau of Economic Research, 2013), many families have continued to experience unemployment and reduced work hours. Except for those in the very highest income brackets, household incomes have not recovered. The present study captures this post-recession period of continued economic turmoil.

Although much attention in times of economic hardship is directed toward the problems of adult workers, little is known about the potential consequences of recessionary times for children's developing outlooks toward the future. Most research focuses on children's academic achievement, finding strong socio-economic gradients (Duncan \& Murnane, 2011; Ermisch, Jantti, \& Smeeding, 2012). Drawing on longitudinal data, we asked three research questions. First, to what extent were parental financial problems and household income associated with children's expectations about success in the economic realm and their educational aspirations in 2011? Second, did change in the family's economic standing between 2009 and 2011 have measurable impacts on change in children's economic expectations and educational aspirations? Finally, were family economic difficulties buffered by, or contingent upon, the family's circumstances and resources, including the parent's history of unemployment, the familial context of achievement as defined by earlier parental achievement orientations and parental educational attainment, or the child's age and gender?

\section{The family and children's achievement orientations}

The importance of children's achievement orientations for their adult attainments is well recognized. According to the classic status attainment model (Sewell \& Hauser, 1975, 1980), parents of higher socio-economic status have higher expectations for their children, which lead them to encourage their children to have high educational and occupational aspirations. Children's aspirations thereby become powerful mediators of the effects of socio-economic status on offspring attainments. Predictions derived from this social psychological model of status attainment have been confirmed in research extending across several decades (Davies \& Kandel, 1981; Hauser, Tsai, \& Sewell, 1983; Kerckhoff, 1995; Sewell \& Hauser, 1976; Sewell \& Shah, 1968; Sewell, Haller, \& Portes, 1969; Sewell, Haller, \& Ohlendorf, 1970; Schoon, this issue). Although adolescents' aspirations and plans have risen greatly in recent cohorts (Reynolds, Steward, MacDonald, \& Sischo, 2006; Schoon, 2010), they continue to predict long-term educational and occupational attainments (Ashby \& Schoon, 2010; Beal \& Crockett, 2010; Farkas, 2011; Jacob \& Linkow, 2011; Reynolds \& Johnson, 2011).

However, aspirations are not the only psychological orientations that may be linked to future attainments (Mortimer, 1994, 1996). In this study we also examine expectations about the likelihood of success in the economic realm. Some youth are optimistic that they will do well in this sphere, while others may not be so sure. Similarly, Bandura's conceptualization of self-efficacy (1977, 1997) highlights beliefs about the likelihood of achieving one's goals. In Bandura's words, "Selfefficacy is concerned with judgments about how well one can organize and execute courses of action required to deal with prospective situations containing many ambiguous, unpredictable, and often stressful elements" (1982: p. 23). Individuals with a stronger sense of self-efficacy set higher goals and exert more effort towards their achievement in the face of obstacles. In one study (Grabowski, Call, \& Mortimer, 2001), adolescents who thought that they would be more economically successful in the future were more likely to take concrete steps to go to college and to achieve high grade point averages. Adolescents' economic expectations were also found to predict successful transitions to adulthood, including young adult educational and income attainments, and the avoidance of early parenting (Lee \& Mortimer, 2009).

Given the significance of children's psychological orientations for their future attainments, it is important to understand where these attitudes come from. Vocational development begins in the family, as parents communicate their orientations toward work and their aspirations for their children to the next generation (Mortimer, 1974, 1975, 1976; Mortimer \& Kumka, 1982; Porfeli \& Vondracek, 2007; Ryu and Mortimer, 1996; Schulenberg, Vondracek, \& Crouter, 
1984; Vondracek et al., 1986). In fact, the parental workplace is probably one of the most critical mesosystem environments (Bronfenbrenner, 1979) influencing children's orientations to the future and their vocational development (Kohn, 1969; Kohn and Schooler, 1983; Vondracek, Lerner, \& Schulenberg, 1986).

While prior work emphasizes the effects of educational aspirations on attainments, aspirations are known to be reflective of the child's academic performance (Reynolds \& Johnson, 2011) and extracurricular activities (Beal \& Crockett, 2010). Children's evaluations of the likelihood of their future economic success could also reflect their prior successes and achievements in school and in work, significant others' reflected appraisals and encouragement, and the presence of successful role models.

In this study we focus on household income and financial strain in the family of origin as potential contributors to children's developing achievement orientations. Elder's "Principle of Linked Lives" (Elder \& Shanahan, 2006; Elder, Johnson, \& Crosnoe, 2003) and his classic study of Children of the Great Depression (1974) indicate that the hard economic times experienced by parents have profound effects on their children's development and attainment. A large body of research has focused on the consequences of income inequality, low income, and poverty on children's cognitive ability (Kainz, Willoughby, Vernon-Feagans, \& Burchinal, 2012; Reardon, 2011; Yeung, Linver, \& Brooks-Gunn., 2002), school dropout, educational attainment (Mayer, 2001), labor force participation, and wages. Researchers have also linked parental financial losses and strain, spousal discord, and parents' strict and erratic disciplinary practices to children's mental health and behavioral problems (Conger, Ge, Elder, Lorenz, \& Simons, 1994; Kainz et al., 2012; Newman, 1988; Walper \& Silbereisen, 1994; Yeung et al., 2002). Although these connections are critical to understanding family processes and child development in the face of economic loss, little is known about how parental economic hardship during the recent recession has influenced children's orientations to their own futures.

In recognition of the complexity of intergenerational transmission and family processes, we examine three categories of potential moderators of the effects of parental hardship on children's orientations: first, the stability of the parental work career, as indicated by unemployment; second, the familial context of achievement, including earlier parental aspirations and economic expectations, and parental educational attainment; and finally, key attributes of the children, including age and gender. Let us consider each one of these in turn.

First, family economic histories may provide interpretive contexts for more immediate experiences. In addition to their direct consequences for children's orientations toward their futures (Schoon, this issue), parents' long-term economic successes and failures could condition the effects of more recent parental experiences in the labor force. At the individual level, developmental growth often follows from adaptive responses to stressful situations; successfully coping with challenges can engender new skills and ways of thinking that enhance resiliency in future similar situations. Shanahan and Mortimer (1996) referred to these situations as eustressful, promoting positive consequences. In contrast, distress and its negative sequelae for mental health are likely to follow from stressors that over-reach the individual's coping abilities (see also Stein, Hoffmann, Bonar, Leith, Abraham, et al., 2013).

Similar processes may be observed at the family level. On the one hand, families that have experienced multiple spells of joblessness over a long period of time could develop coping mechanisms to adapt to such situations; in response to early shocks, the family could have learned how to obtain other sources of income, goods and services, as well as social support (Iverson, Napolitano, \& Furstenberg, 2011). Efforts to "cut back" could have become routinized and reductions to living standards minimized. If such adaptive strategies were readily enlisted each time the parent suffered a new set of drawbacks, there could be few deleterious effects of these experiences on children.

It is also plausible, however, that earlier economic problems, especially if their repercussions were traumatic, could "sensitize" both parents and children to economic decline, reducing thresholds of vulnerability (Shanahan \& Mortimer, 1996). The family's inability to adequately cope with economic 
hardship in prior years might have precipitated declines in parental efficacy and mental health (Conger et al., 1994), which reduce adequate coping in similar situations. In this case, earlier bouts of unemployment could exacerbate the effects of current hardships on children's orientations to the future (Prawitz, Kalkowski, \& Cohart, 2013). A third possibility is that the family's economic history does not matter; instead, only the immediate economic circumstances of the family influence children's achievement-related orientations. In our research, we empirically estimated the impacts of the parent's long-term unemployment history and current economic circumstances.

Second, we investigate the possible conditioning effects of the familial context of achievement, considering parental traits that may be highly durable. That is, we assess whether the parent's own achievement orientations to the future, measured in adolescence, have long-term implications for their children. Much research in the status attainment tradition has shown that parents' contemporaneous expectations for their children's educational attainment have strong effects on children's actual educational achievement and adult socio-economic attainment (for a summary, see Kerckhoff, 1995). However, parents' earlier expectations regarding their own futures during adolescence, could have influenced their own achievements and could also be reflected in their expectations, as adults, for their children. To the extent that parental achievement orientations are long-term stable traits, affecting confidence in the face of adversity, they could be communicated to the child and potentially buffer the effects of financial hardships on children.

Moreover, since parental education is a key indicator of family socio-economic status, which has strong implications for parental orientations toward their children's achievement, it may also function to condition the effects of economic hardship. Elder (1974), in Children of the Great Depression, noted that the status losses of formerly middle-class parents led them to experience greater mental anguish than working-class parents. It is likely that highly educated contemporary parents, with their emphasis on the "concerted cultivation" (Lareau, 2002, 2003; Reardon, 2011) of children's development and socio-economic attainment, would continue to encourage their children's achievement despite economic hardships.
Finally, we examine whether the child's age or the child's gender buffer the effects of family hardship on children's achievement orientations. While longitudinal studies indicate that gaps in educational achievement by family income remain quite stable as children age (Reardon, 2011), children's achievement orientations may reflect their families' economic problems to a greater or lesser extent, depending on their age. Elder and Rockwell (1979) found that the young children in the Berkeley cohort were more vulnerable during the Great Depression, as they had little understanding of the reasons for their parents' upset, and they could do nothing to help their parents at this time of crisis. Older children in the Oakland cohort, who experienced the Depression as teenagers, could understand that their parents were affected by a broad nation-wide economic crisis, and they could help their parents through their odd jobs and contributions to household work. Elder interpreted their longerterm positive outcomes as attributable to their experiences of successful coping. Analyses of more recent data from the Panel Study of Income Dynamics show that low family income experienced in early childhood (birth to age 5) has more detrimental effects on life chances (as indicated by years of completed schooling and high school graduation) than poverty experienced at older ages (Duncan, Brooks-Gunn, Yeung, \& Smith, 1998). However, in a study in New York state, Halpern-Felsher, et al. (1997) assessed children and adolescents' educational risk (as measured by an index reflecting standardized achievement test scores, school attendance, suspension and other problems), comparing those who were eligible for free or reduced lunch programs with those who were not. While family economic risk had no significant effects on educational risk among those in middle childhood (mean age 9.8); with the exception of African-American males, it increased educational risk among adolescents (mean age 15.6). Given these mixed findings, our assessment of the moderating effects of child age is exploratory.

Although most young people aspire to work as adults, and boys and girls assign commensurate importance to their future occupational careers (Johnson \& Mortimer 2000), gender differences in educational attainment, labor force participation, and earnings persist. Young adult women in the United States have now surpassed men in their educational 
achievement (Institute of Education Sciences, 2011), but young women's earnings continue to lag behind men's at every level of educational attainment (U.S. Bureau of the Census, 2011). Since normative expectations still confer main breadwinner status on men (Johnson, Oesterle, \& Mortimer, 2001), boys may be more sensitive than girls to parents' setbacks and successes in the world of work, and therefore more responsive to their parents' successes and failures. Consistent with this expectation, Schoon and her colleagues (Schoon, Martin \& Ross, 2007) reported that 16 year-old males were more susceptible to their parents' economic hardship than females (see also, Schoon, this issue). Their study of two nationally representative British birth cohorts (1958 and 1970) indicated that parental economic hardship diminished job aspirations among teenage sons, but not daughters. Similarly, Rutter (1970) reported greater child responsiveness to marital discord and family disruption, common responses to economic stress, among males than females.

In view of the extensive literature on parental success and children's achievement orientations, our study was guided by four hypotheses. The first hypothesis posits direct effects; the remainder reference moderating influences.

I. Children's economic expectations and educational aspirations will reflect recent and past parental economic hardship, controlling parental orientations to achievement, parental education, and the child's age and gender.

II. The parent's prior history of unemployment will moderate the effects of parents' current economic well-being on children's achievement-related orientations. With little prior research, and plausible reasons to expect "inoculating" as well as "sensitizing" effects of prior hardship, our assessment of the contingent effects of parental unemployment history is exploratory.

III. A positive familial context of achievement, as indicated by the parents' orientations to achievement when they were adolescents and the parents' educational attainment, will reduce the effects of economic hardship.

IV. Parental economic standing will have more deleterious effects for boys than girls.

\section{Methods}

\section{Data source}

The data were obtained from the longitudinal Youth Development Study, which has followed a panel of 1,139 randomly chosen teenagers since 1988 when they were in the 9th grade in the St. Paul Minnesota Public Schools and mostly $14-15$ years old (Mortimer, 2003). Nineteen near-annual surveys have been obtained from the participants, first administered in their high school classrooms, and subsequently by mail, through 2011, when the respondents were 37 and 38 years old. Panel retention in recent years, at about 67 percent of the original cohort, was not associated with numerous indicators of socio-economic origin, achievementrelated orientations measured in adolescence, extrinsic and intrinsic work values, behavioral problems and mental health. However, men and nonwhites have had a higher risk of survey attrition than women and whites.

In 2008, we began to recruit the children of this cohort, targeting those who were age 11 and older (Hussemann, Mortimer, \& Zhang, 2011). The first data collection (a mailed survey) from children occurred in 2009, with 277 responding. We continued recruiting children for waves 2 and 3 of the child study (again targeting those children who turned 11, as well as older children who had not joined the study previously); by 2011, 67 percent of the eligible parents had allowed their children to participate. Mothers were more likely to consent than fathers, parental education was positively related to consent, and parents were more likely to allow their biological children to participate than stepchildren or adopted children. Parental marital status (single, cohabiting, married), household income, and parental financial problems were not significantly related to the consent decision.

By 2011 (Wave 3 of the child study), 449 children had been recruited, of whom 345 completed Wave 3 surveys. To maximize sample size, our initial analyses draw on child orientations measured in 2011. We then estimated first difference models that utilized data obtained from 186 children and their parents who completed surveys in both 2009 and 2011 (excluding children who did not age into the sample until after 2009, as well as those not participating in 
one wave or the other). We used data from parents collected both contemporaneously and previously.

We do not claim that this sample is representative of children or families in the Twin Cities (St. Paul and Minneapolis) area; nor does it represent the larger Youth Development Study cohort from which it was drawn. This is because we recruited only children age 11 and older, whose mean age was 15.8 in 2011. Since parents were all about the same age, born in 1973 or 1974, parents of children of mean age ( 16) in 2011 would have been in their early twenties at the time of the child's birth; parents of older children were even younger. Thus, as one might expect, our sample of parents has lower educational attainment and incomes than the panel as a whole, and is also disadvantaged in comparison to all families of approximately the same age in the Twin Cities. In Minneapolis and St. Paul, 49.6 percent of 35-40 yearolds had a Bachelor's degree or higher in 2011; in our sample of parents, only 21 percent had attained this level of education. While median household income in our sample of families was $\$ 65,000$ in 2011 , for 3540 year olds in Minneapolis and St. Paul, median household income was $\$ 81,400$ (authors' calculations based on the 2011 American Community Survey, Ruggles, et al. 2010).

To further contextualize this study, it should be recalled that these data were obtained in the years following the official "Great Recession." Because of the persistence of unemployment and other economic difficulties, this recession has had "a long tail," with many families continuing to experience hardship after its official end. In the Twin Cities Metropolitan Statistical Area, the unemployment rate in 2011 was 6.3 percent, lower than the peak rate of 7.9 percent in 2009, but still not down to the 4.4 percent unemployment rate experienced in 2007 (Bureau of Labor Statistics, 2013a, b, and c).

\section{Measures}

\section{Children's achievement orientations in 2009 and 2011}

Children's economic expectations were based on their responses to the question: "How do you see your future?" Three items followed: (1) "You will have a job that pays well?" (2) "You will be able to own your own home?" and (3) "You will have a job that you enjoy doing?" Response options ranged from (1) Very low to (5) Very high. We summed responses to the three questions to create unstandardized additive indices (Alpha=.824 in 2009; .840 in 2011). Elsewhere these questions have also been used to measure life course expectations or optimism about the future (Hitlin \& Johnson, 2013). Children's educational aspiration was based on a single question: "What is the highest level [of education] that you plan to obtain in the future?" Responses ranged from (1) elementary or junior high school to (6) Ph.D. or professional degree.

\section{Family economic indicators}

Annual household income was calculated by taking the natural logarithm of income, as indicated by the response to the open-ended question, "What was the income for your entire household in 2010 before taxes?" The natural logarithm of annual household income for each year and differences between those two natural logarithms (in first difference models) were used to approximate the normality assumption of OLS.

An additive financial problems index (AFPI) was based on the sum of responses to three items: (1) "How much stress have you felt in meeting your financial obligations during this past year?"; (2) "How difficult is it for you to pay your bills on time? These bills might include insurance, rent, mortgages, car payments, credit cards, etc."; and (3) "How much burden do you feel from debt (from credit cards, mortgages, personal loan, etc.?)." Responses ranged from 1, "No burden (stress or difficulty) at all," to 7, "Extremely high burden (stress or difficulty)." (Alpha=.857 in 2009; .886 in 2011).

\section{Parental unemployment history}

Parents' unemployment history was based on an annual Life History Calendar, which recorded monthly employment status over the 11 years prior to the onset of the current recession, from January 1997 to December 2007. The average annual proportion of unemployed months was calculated as number of months unemployed/12, divided by the number of available years. (Since not all respondents completed surveys in every wave, the total available years can be less than 11.) In regressions, the continuous measure 
of average annual proportion of unemployment is further grouped into three categories: zero unemployment experience over the entire period, approximately one month unemployment on average per year, and more than one month unemployment per year. Zero unemployment experience is the reference group under the dummy coding scheme.

\section{Family context of achievement}

The indicators of parental achievement orientations, measured when they were 15-16 years old, in the second year of high school, are identical to the children's measures of economic expectations and educational aspirations. Parents' educational attainment was grouped into three categories: (1) High school or less (the reference category); (2) Technical or vocational school, an Associates' degree, or some college; and (3) BA or above.

\section{Child age and gender}

Child age was measured in years, and gender was coded 1 if male.

\section{Analytic strategy}

We initially used Ordinary Least Squares regression to assess the effects of parental economic status on children's achievement-related outcomes in 2011. For each child outcome, economic expectations and educational aspirations, we examined the main effects of each contemporaneous economic status variable (additive financial problems index and the natural logarithm of annual household income) to assess their independent effects, net of the parent's achievement orientations in adolescence, parental education, and the child's age and gender. We assessed these variables one at a time, to take advantage of the full number of cases for which we have data (parents were more willing to divulge their financial problems than their household incomes). We then examined whether parental unemployment history, earlier parental orientations (observed in adolescence), parental educational attainment, child age, or child gender moderated the effects of the family economic status variables on children's outcomes, by introducing interaction terms and examining their effects one at a time. We examined all possible interactions between the two 2011 hardship indicators and parental unemployment history, parental achievement orientations, parental education, child age, and child gender; however, only statistically significant interactions are reported in the tables. In this way we highlight potentially important conditioning effects. Unstandardized regression coefficients are reported for the 2011 models.

In a second step, for each outcome in turn, we examined first-difference models in which both financial hardships and children's outcomes were expressed as the difference between respondents' 2011 and 2009 values (2011 minus 2009 measures). This allowed us to assess the impacts of change in economic hardship on change in children's orientations directly, and to examine how such impacts might be moderated by parental unemployment histories, earlier parental orientations, parental educational attainment, child gender, and child age. This strategy (the simplest case of the fixed effect model, see Allison, 2009, pp. 7-27; Wooldridge, 2002, pp. 279-291), controls the additive effects of timeinvariant qualities of parents and children, which could influence parental economic hardship or the attitudes of the children. The first-difference models therefore offer the most stringent test of our hypotheses since time-stable characteristics of parents and children are effectively controlled. Like before, we generated unstandardized regression coefficients; only those interaction effects that were statistically significant are reported.

Because children are nested within families, they cannot be treated as independent observations; that is, clustering jeopardizes the assumption that regression error terms are independent of one another. Therefore, the significance levels of the regression coefficients were calculated with adjusted standard errors, using the "cluster" option in STATA's regression command. (For the formula for determining the robust cluster variance estimator, see Sribney, 2009; for further description of clustercorrelated robust variance estimates, see Froot, 1989; Rogers, 1993; Williams, 2000; and Wooldridge, 2002). 


\section{Findings}

Descriptive statistics for the 2011 sample are reported in Table 1; changes in child economic expectations, aspirations, log household income, and the additive financial problems index from 2009 to 2011 are also shown. The children's 2011 economic expectations indicators are relatively high, with means about 4.0 (the maximum value was 5); the additive expectations index is also shown. Consistent with many other studies (e.g., Reynolds et al., 2006; Schoon, 2010), 2011 educational aspirations among the children were also quite high at 4.5 (approximating a Bachelor's degree). Mean household income, measured in 2011 , was $\$ 60,990$. The parents, on average, reported moderate levels of financial problems; the average value of this scale (range 3-21) was about 13. In the eleven-year span from January 1997 to December 2007, parental unemployment on average was a little less than three weeks annually (e.g. $0.05 \times 12$ months $\times 31$ days $=\sim$ 19 days); 51 percent of parents had no unemployment experience from 1997 to 2007, 26 percent were unemployed one month, on average, per year, and 24 percent were unemployed more than one month, on average, per year.

The parental economic expectations index, measured during the parent's adolescence at age 1516 (in year 1989), is just slightly lower than the same measure for children. Parental educational aspirations, as adolescents, were lower than their children's, approximating some college. The modal parental educational level, achieved by 57 percent of the parents, also approximated an Associate's degree, some college, or vocational/technical certification.

The mean child's age was 15.8 in 2011 and 45 percent were male.

\section{Children's economic expectations}

We first considered the children's economic expectations, the variable that might appear to be the most strongly affected by parental economic standing. Children's economic expectations reflect their perception that they themselves will be economically successful in the future. Table 2 presents OLS unstandardized coefficients for the 2011 models of children's expectations. It should be noted that the number of cases and clusters, or families, differs across models, because some parents and/or children did not answer all questions. For example, models including household income are based on fewer cases, since some parents did not report their incomes.

Model 1 in Table 2 shows that parents' financial problems had no significant main effect on child expectations; however, children's expectations rose with the natural logarithm of parental household income (Model 2; b=.345, p<.05). The parent's economic expectation, measured during adolescence, also had a significant positive effect on their children's expectation (Model 1; b=.145, $p<.05$ ), measured more than 20 years later. This positive effect suggests a process of inter-generational transmission. Such positive expectations may be considered a stable trait, manifest over a long period of time and transferred to children via a wide range of communications and cues. In Model 1, children whose parents were in the highest education bracket (BA or more) had significantly higher economic expectations than children whose parents were in the lowest reference category (high school or less). The effect of high parental education becomes insignificant, however, when household income is controlled (Model 2). Interestingly, children whose parents were in the intermediate educational category did not have higher expectations than the children in the lowest, least well-educated group in either specification. We found no significant interactions dependent on parental unemployment experience, earlier parental expectations, parental education, child's age or gender.

To investigate whether change in the family's economic circumstances led to change in children's expectations from 2009 to 2011, we estimated firstdifference models, initially examining main effects (see Table 3, Models 1 and 2). The economic variables (change in log income, change in financial problems) were found to have no significant main effects. While first-difference models control the additive effects of variables that are constant across time, it is still possible that such constant variables could interact with changing characteristics to produce variant outcomes. We therefore assessed whether prior unemployment experience, earlier parental expectations, parental education, or child 
Table 1. Descriptive Statistics

\begin{tabular}{|c|c|c|c|c|c|}
\hline Variable & $\mathbf{N}^{*}$ & Mean & S.D. & Min & Max \\
\hline \multicolumn{6}{|l|}{ Child 2011} \\
\hline Child Economic Expectation Index & 325 & 12.07 & 2.28 & 4 & 15 \\
\hline Chances to have a job that pays well & 325 & 3.98 & 0.83 & 1 & 5 \\
\hline Chances to have your own home & 325 & 4.04 & 0.92 & 1 & 5 \\
\hline Chances to have a job that you enjoy & 325 & 4.05 & 0.88 & 1 & 5 \\
\hline Child Educational Aspiration & 314 & 4.47 & 1.21 & 2 & 6 \\
\hline Child Age & 343 & 15.83 & 2.85 & 11 & 23 \\
\hline Child Gender (Male = 1) & 344 & 0.45 & 0.50 & 0 & 1 \\
\hline \multicolumn{6}{|l|}{ Parent 2011} \\
\hline Annual Household Income $(\$ 1000)$ & 175 & 60.99 & 34.18 & 0.04 & 135 \\
\hline Log Annual Household Income & 175 & 10.74 & 1.01 & 3.76 & 11.81 \\
\hline Parent's Education & 208 & & & & \\
\hline Less than or Equal to High School (ref) & & 0.22 & 0.41 & 0 & 1 \\
\hline Tech / Vocational school or Some college & & 0.57 & 0.50 & 0 & 1 \\
\hline B.A. degree or higher & & 0.22 & 0.41 & 0 & 1 \\
\hline Additive Financial Problems Index & 208 & 12.82 & 5.13 & 3 & 21 \\
\hline Average Annual Proportion of Unemployment & 231 & 0.05 & 0.10 & 0 & 0.64 \\
\hline Zero Unemployed Months & & 0.51 & 0.50 & 0 & 1 \\
\hline One month on average per year & & 0.26 & 0.44 & 0 & 1 \\
\hline > one month on average per year & & 0.24 & 0.43 & 0 & 1 \\
\hline \multicolumn{6}{|l|}{ Parent 1989 (in adolescence) } \\
\hline Parent's Educational Aspiration in 1989 & 202 & 3.67 & 1.28 & 1 & 6 \\
\hline Parent's Economic Expectation Index in 1989 & 225 & 11.71 & 2.43 & 3.96 & 15.44 \\
\hline Chances to have a job that pays well & 225 & 3.71 & 0.83 & 1 & 5 \\
\hline Chances to have your own home & 225 & 3.70 & 1.01 & 1 & 5 \\
\hline Chances to have a job that you enjoy & 225 & 4.02 & 0.84 & 1 & 4 \\
\hline \multicolumn{6}{|l|}{ Changes between 2009 and 2011} \\
\hline \multicolumn{6}{|l|}{ Child 2011-2009 } \\
\hline Economic Expectation & 162 & 0.08 & 2.39 & -9 & 12 \\
\hline Educational Aspirations & 160 & 0.05 & 1.42 & -4 & 5 \\
\hline \multicolumn{6}{|l|}{ Parent 2011-2009 } \\
\hline Log Annual Household Income & 107 & 0.002 & 0.96 & -7.06 & 2.64 \\
\hline Additive Financial Problems Index & 136 & 0.46 & 4.08 & -9 & 14 \\
\hline
\end{tabular}

*N's for G1/G2 are counts of unique parents/ families and N's for G3 are counts of unique G3 children. 
Table 2. OLS Models for 2011 Child Economic Expectation

\begin{tabular}{lcc} 
Economic Expectation & $\mathbf{1}$ & $\mathbf{2}$ \\
\hline Child's Age & -0.071 & -0.037 \\
Child Gender (Male=1) & $(0.043)$ & $(0.045)$ \\
& -0.196 & -0.175 \\
Parent's Economic Expectation (1989) & $(0.270)$ & $(0.285)$ \\
& $0.145^{*}$ & $0.110^{*}$ \\
Tech/vocational/some college & $(0.057)$ & $(0.051)$ \\
& 0.384 & 0.385 \\
B.A. And above & $(0.372)$ & $(0.428)$ \\
& $0.862^{*}$ & 0.650 \\
Additive Financial Problems Index & $(0.408)$ & $(0.474)$ \\
& 0.005 & \\
Log Annual Household Income & $(0.026)$ & \\
& & $0.345^{*}$ \\
Constant & & $(0.160)$ \\
& $11.160^{* * *}$ & $7.524 * * *$ \\
\hline N & $(0.960)$ & $(1.990)$ \\
R-families & 289 & 248 \\
\hline * $p<0.05, * * p<0.01, * * * p<0.001$ & 192 & 162 \\
& 0.069 & 0.079 \\
\hline
\end{tabular}

age and gender, moderated the effects of the two economic change indicators.

We observed two significant interactions. First, parental economic expectations, observed during the parents' adolescence, conditioned the effect of change in household income between 2009 and 2011. The significant coefficient for the difference in log annual household income in Table 3 Model 3 indicates that children's economic expectations declined somewhat as parental incomes rose, when parents had the lowest economic expectations ( $b=-$ $1.779, p<.05)$. The significant coefficient for the interaction term $(b=.194, p<.01)$ indicates that with increases in parental economic expectations, increases in parental income have salutary effects on children's economic efficacy. Thus, an increase from a parental expectations score of 4 , the lowest, to 15 , the highest, would yield a positive effect of each unit increase in log household income on child expectations $(-1.779+[11 \times .194]=.355)$. To depict this interaction more intuitively, Figure 1 shows differences in the effects of change in household income for children whose parents' economic expectations, as adolescents, were above and below the median. It is evident that increases in household income only strengthen children's economic expectations when the parents themselves had relatively high expectations (above the median) as adolescents. Perhaps high expectations reflect the parent's perception of self as an agentic and effective economic actor---leading parents to attribute their economic successes (and failures) to their own 
Table 3. First-difference Models for Economic Expectation

\begin{tabular}{|c|c|c|c|c|}
\hline Diff. in Economic Expectation & 1 & 2 & 3 & 4 \\
\hline Diff. log annual household income & $\begin{array}{c}0.245 \\
(0.128)\end{array}$ & & $\begin{array}{l}-1.779 * \\
(0.679)\end{array}$ & \\
\hline Diff. additive financial problems index & & $\begin{array}{l}-0.006 \\
(0.045)\end{array}$ & & $\begin{array}{l}-0.226^{* *} \\
(0.084)\end{array}$ \\
\hline Parent's Economic Expectation (1989) & & & $\begin{array}{c}0.035 \\
(0.058)\end{array}$ & $\begin{array}{c}0.021 \\
(0.061)\end{array}$ \\
\hline Tech/vocational/some college & & & & $\begin{array}{l}-0.050 \\
(0.413)\end{array}$ \\
\hline B.A. and above & & & & $\begin{array}{c}0.123 \\
(0.595)\end{array}$ \\
\hline Tech/vocational/some college $\times$ Diff. AFPI & & & & $\begin{array}{l}0.312^{* *} \\
(0.096)\end{array}$ \\
\hline B.A. and above $\times$ Diff. AFPI & & & & $\begin{array}{c}0.223 \\
(0.120)\end{array}$ \\
\hline $\begin{array}{l}\text { Parent's Economic Expectation (1989) } \times \text { Diff. log household } \\
\text { income }\end{array}$ & & & $\begin{array}{l}0.194^{* *} \\
(0.066)\end{array}$ & \\
\hline Constant & $\begin{array}{c}0.021 \\
(0.209)\end{array}$ & $\begin{array}{c}0.084 \\
(0.182)\end{array}$ & $\begin{array}{l}-0.370 \\
(0.679)\end{array}$ & $\begin{array}{l}-0.089 \\
(0.784)\end{array}$ \\
\hline $\mathrm{N}$ & 124 & 162 & 120 & 157 \\
\hline $\mathrm{N}$-families & 96 & 124 & 93 & 120 \\
\hline R-square & 0.014 & 0 & 0.027 & 0.056 \\
\hline
\end{tabular}

${ }^{*} p<0.05,{ }^{* *} p<0.01,{ }^{* * *} p<0.001$

abilities and effort---and to communicate these interpretations to their children. Conversely, if the family's economic welfare declines despite relatively high levels of parental expectations about the future, children's confidence in their own capacity to achieve economic goals in adulthood may erode. In this case, we conclude that high parental economic expectations, sensitize the child to the effects of rising (or falling) incomes.

Second, parental education moderated the effect of change in parental financial problems on children's expectations. In the specification for Table 3 Model 4, the coefficient for change in financial problems $(b=-$ $.226, p<.01$ ) indicates that increasing financial problems have a negative effect on expectations among children of the least well- educated parents (the reference group). The coefficient for the interaction of the intermediate level of education (technical, vocational, some college) with change in the financial problems index, which is positive $(b=.312, p<.01)$, indicates the difference between the effect for this group and the reference group. Thus, a one-unit increase in parental financial problems leads to a small increase of $-.226+.312=.086$ in the child's economic expectation, if parents had the intermediate level of educational attainment. As shown in Figure 2, as parental financial problems increase, children of the least well-educated parents show a sharp decline in expectations. The slightly upward slope for children whose parents have intermediate levels of education indicates that their expectation increases as parents grapple with financial stresses. Children of the most highly educated parents (with BA degrees and above) show virtually no change in economic expectations despite increasing parental financial problems. No other significant interaction effects were observed. 
Figure 1 Change in Log Annual Household Income and Change in Child Economic Expectation,

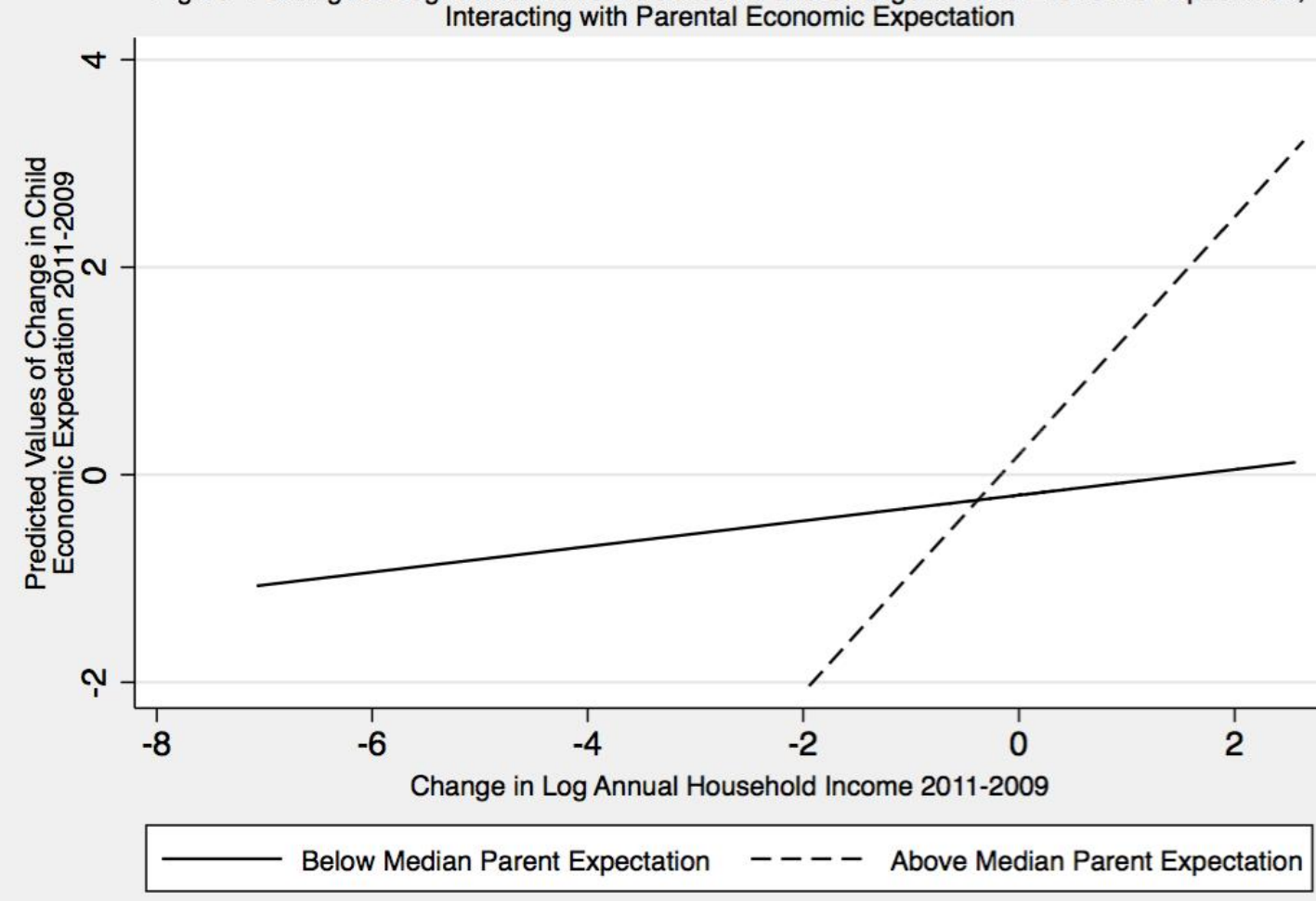

Figure 2 Change in Financial Problems Index and Change in Child Economic Expectation, Interacting with Parental Education

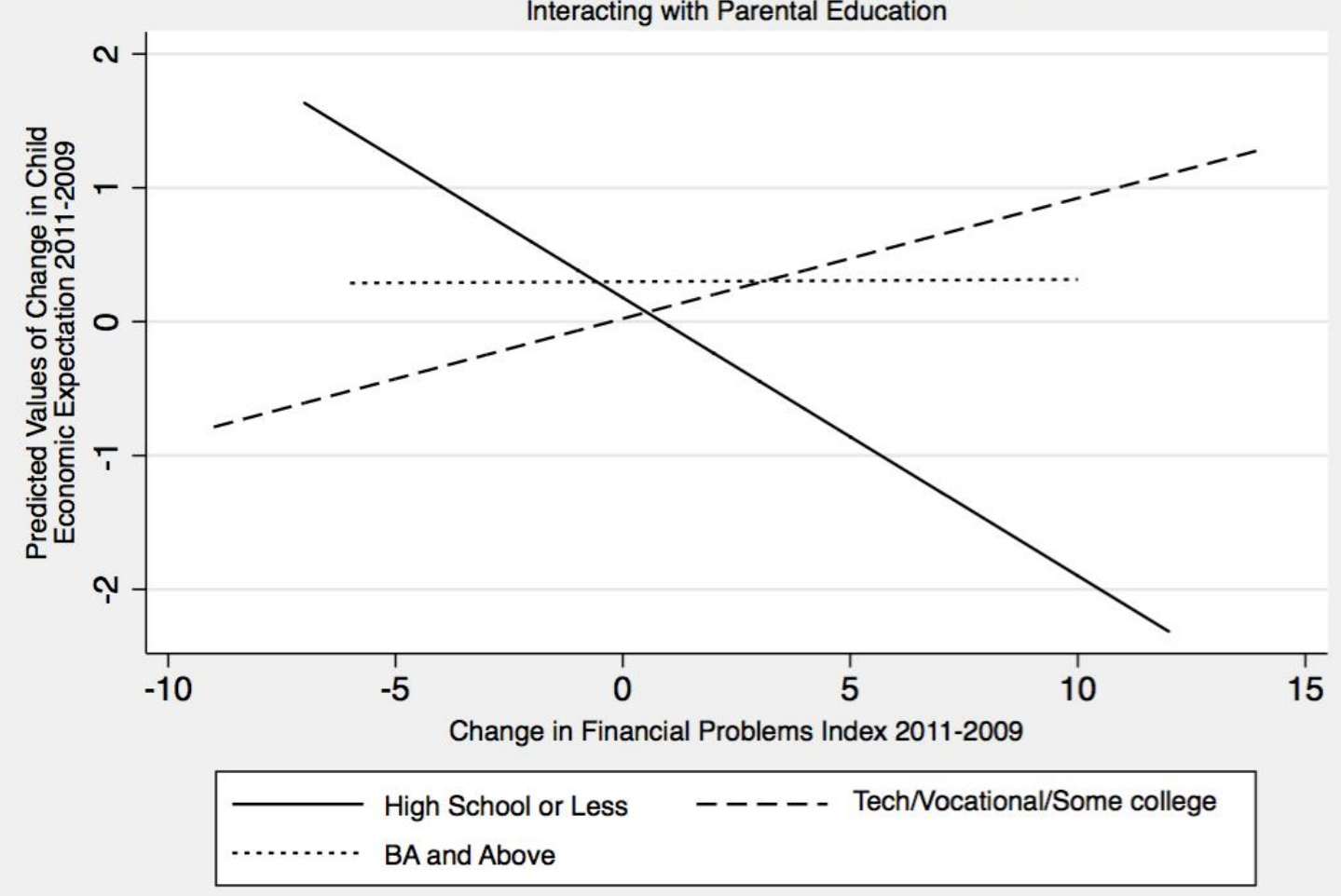




\section{Children's Educational Aspirations.}

Models 1 and 2 in Table 4 show that neither the parental financial problems index, nor household income, have significant effects on children's educational aspirations. Unlike parental economic expectations, parental educational aspirations, measured during adolescence, did not significantly predict the child's aspiration in 2011. Consistent with decades of research on children's aspirations (see also Schoon, this issue), children whose parents had a Bachelor's degree or more had higher educational aspirations than children whose parents had no postsecondary educations. Aspirations decline with age, and boys have lower educational aspirations than girls.

We find three significant interactions. First, we found evidence that the parent's unemployment history sensitized the child to economic conditions in the household (see Table 4, Model 3). The log of household income had no significant effect on the educational aspirations of children whose parents experienced no unemployment from 1997 to 2007 ( $b=-.180$, n.s.). Increase in log household income had a positive effect on aspirations among those whose parents suffered relatively little unemployment during the decade prior to the recession $(-.180+.334=.154)$. The results indicate that the parent's smooth employment history protects the child's educational aspirations when household incomes are low. In contrast, the positive coefficients for the children of those parents who suffered unemployment (non-significant, however, for the children of parents who suffered more than one month of unemployment per year) suggest that aspirations rise (or fall) with shifts in parental economic fortunes.

Figure 3 illustrates the interaction between unemployment experience and the natural logarithm of 2011 income. The solid line, representing the impacts of household income on aspirations for children of parents without any unemployment, slopes downward (a non-significant trend, as shown in Table 4), while the dashed and dotted lines for parents with unemployment experience have positive slopes. This pattern suggests that prior sporadic unemployment experience increases the child's responsiveness to income differences, as aspirations rise as household income increases (or fall as income declines) only among children whose families may have become "sensitized" to economic hardship and economic betterment.

Second, although parental educational aspiration in adolescence had no significant additive effect (Table 4, Model 1), it moderated the effect of parental financial problems (Model 4). The coefficient for the financial problems index, -.094 $(p<.05)$ in Model 4, may be interpreted as the effect of financial problems for children whose parents had the lowest educational aspirations in adolescence. The effect of financial problems becomes less negative as earlier parental educational aspirations increase. To illustrate this effect more concretely, Figure 4 shows differences in the effects of financial problems for the children of parents who aspired to a $\mathrm{BA}$ or more during adolescence, and those whose parents aspired to less than a BA. As shown in Figure 4, when financial problems rise, there is a steep decline in children's aspirations for children whose parents aspired to less than a BA. In contrast, when parents had high aspirations as adolescents, their children's aspirations are relatively impervious to parents' increasing financial difficulties. High parental aspirations, early on, thus appear to be protective for their children.

Finally, child gender conditions the impacts of parental financial problems (Table 4, Model 5); while parents' financial problems had no significant impact on girls' aspirations $(b=.037$, n.s.), the difference in the effect of financial problems for boys and girls was statistically significant and negative $(b=-.066, p<.05)$. Thus, boys' educational aspirations declined slightly (.037-.066=--.029) as their parents' financial strain increased.

We next investigated "changes-on-changes" with first-difference models. The coefficients in Table 5 suggest that change in two measures of economic hardship - household income and financial strain had no significant main effects on change in children's educational aspirations (Models 1 and 2). However, we found evidence that aspirations declined in the face of increasing parental financial strain again in the group with below-median levels of unemployment. For parents without any unemployment experience in 


\section{Table 4. OLS Models for 2011 Educational Aspiration}

\begin{tabular}{|c|c|c|c|c|c|}
\hline Educational Aspiration & 1 & 2 & 3 & 4 & 5 \\
\hline \multirow[t]{2}{*}{ Child's Age } & $-0.075^{* *}$ & $-0.064^{*}$ & $-0.062^{*}$ & $-0.082 * *$ & $-0.076^{* *}$ \\
\hline & $(0.027)$ & $(0.029)$ & $(0.028)$ & $(0.027)$ & $(0.027)$ \\
\hline \multirow[t]{2}{*}{ Child Gender (Male = 1) } & $-0.505^{* * *}$ & $-0.475^{* *}$ & $-0.503 * *$ & $-0.524 * * *$ & 0.363 \\
\hline & $(0.150)$ & $(0.158)$ & $(0.156)$ & $(0.147)$ & $(0.406)$ \\
\hline \multirow[t]{2}{*}{ Parent's Educational Aspiration (1989) } & -0.082 & -0.089 & -0.117 & $-0.477^{* *}$ & -0.069 \\
\hline & $(0.067)$ & $(0.075)$ & $(0.073)$ & $(0.154)$ & $(0.068)$ \\
\hline \multirow[t]{2}{*}{ Tech/Vocational/Some college } & 0.267 & $0.435^{*}$ & 0.346 & 0.263 & 0.233 \\
\hline & $(0.211)$ & $(0.206)$ & $(0.215)$ & $(0.208)$ & $(0.210)$ \\
\hline \multirow{2}{*}{ B.A. and above } & $0.632 *$ & $0.711^{* *}$ & $0.709 * *$ & $0.660 * *$ & $0.543^{*}$ \\
\hline & $(0.253)$ & $(0.258)$ & $(0.259)$ & $(0.243)$ & $(0.262)$ \\
\hline \multirow[t]{2}{*}{ Additive Financial Problems Index } & 0.007 & & & $-0.094^{*}$ & 0.037 \\
\hline & $(0.016)$ & & & $(0.046)$ & $(0.020)$ \\
\hline \multirow[t]{2}{*}{ Log Annual Household Income } & & 0.111 & -0.180 & & \\
\hline & & $(0.113)$ & $(0.127)$ & & \\
\hline One month on average Unemployment & & & $-3.600 *$ & & \\
\hline Experience & & & $(1.805)$ & & \\
\hline > one month on average Unemployment & & & -4.613 & & \\
\hline Experience & & & $(2.782)$ & & \\
\hline \multirow[t]{2}{*}{ Child's Gender × AFPI } & & & & & $-0.066^{*}$ \\
\hline & & & & & $(0.031)$ \\
\hline One month on average Unemployment Exp. $\times$ Log & & & $0.334 *$ & & \\
\hline Annual Income & & & $(0.165)$ & & \\
\hline > one month on average Unemployment Exp. $x$ & & & 0.398 & & \\
\hline Log Annual Income & & & $(0.270)$ & & \\
\hline Parental Educational Aspiration (1989) × Financial & & & & $0.028 *$ & \\
\hline Problems Index & & & & $(0.011)$ & \\
\hline \multirow[t]{2}{*}{ Constant } & $5.845^{* * *}$ & $4.421^{* *}$ & $7.791^{* * *}$ & $7.387^{* * *}$ & $5.452 * * *$ \\
\hline & $(0.544)$ & $(1.522)$ & $(1.638)$ & $(0.805)$ & $(0.560)$ \\
\hline $\mathrm{N}$ & 253 & 221 & 221 & 253 & 253 \\
\hline N-families & 171 & 147 & 147 & 171 & 171 \\
\hline R-square & 0.099 & 0.124 & 0.157 & 0.125 & 0.118 \\
\hline
\end{tabular}

$p<0.05,{ }^{* *} p<0.01,{ }^{* * *} p<0.001$ 

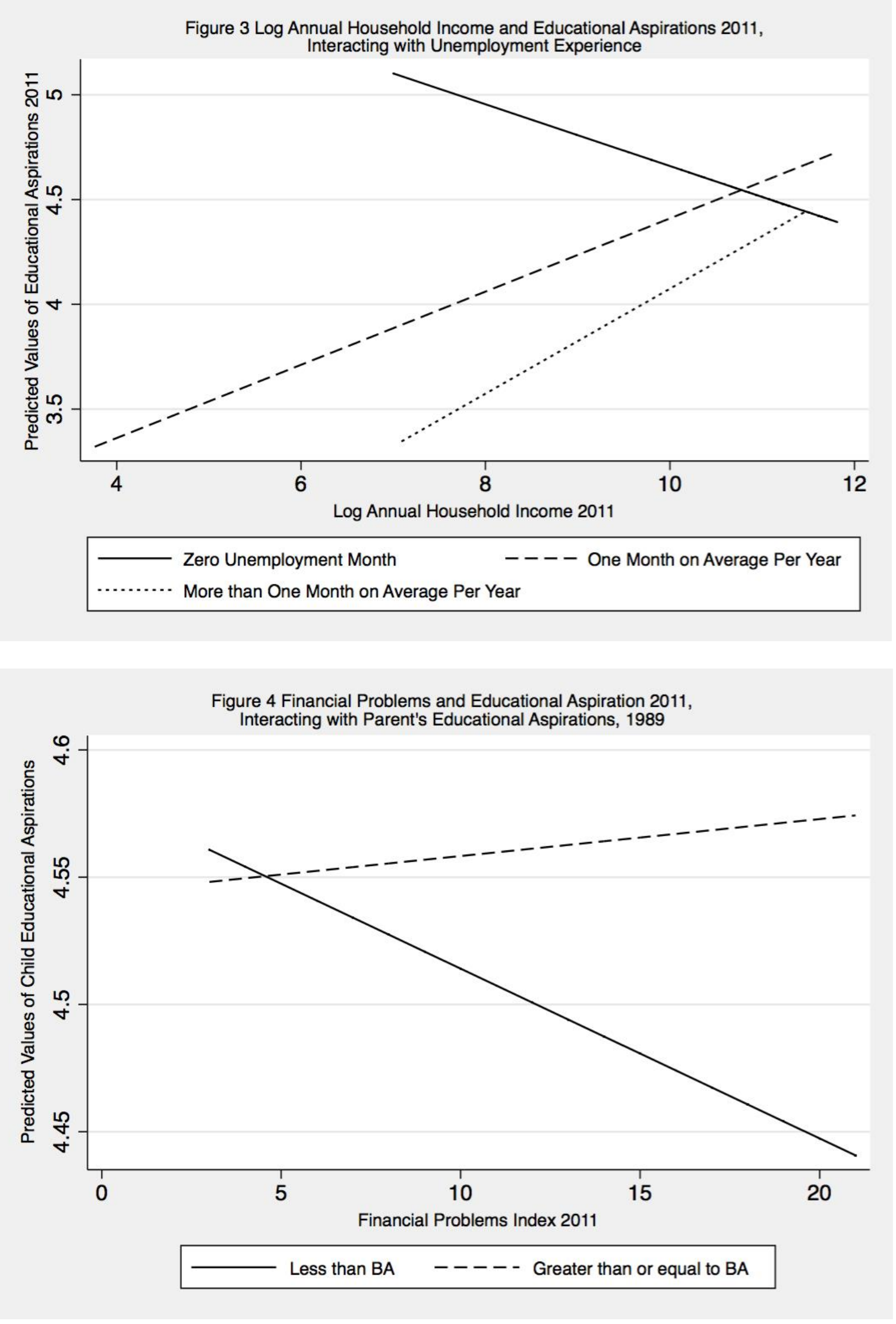
the 11-year interval between January 1997 and December 2007, changes in financial problems between 2009 and 2011 were not reflected in change in their children's educational aspirations $(b=.042$, n.s.). In contrast, for parents with low levels of unemployment during the same time span, a one-unit increase in financial problems had a significantly more negative effect (that is, $b=-.158, p<.05 ; .042-.158=$ -.116) on their children's educational aspirations. This interaction effect is illustrated in Figure 5. The solid line, representing the effect of increasing financial strain on change in aspirations for the children whose parents experienced no unemployment, is relatively flat. Only the children whose parents experienced about one month of unemployment per year exhibited decline in aspirations as parental strain rose. The dotted line, for the children of parents who experienced the most unemployment, is somewhat positive. It should be noted, however, that the difference between the effect of increasing financial problems for children of parents who suffered unemployment for more than a month per year is not significantly different from the effect for children whose parents had no unemployment experience during the past decade (Table 5, Model 3). Still, this trend is difficult to interpret. We speculate that when the parents have experienced some unemployment in the face of the family's financial problems, children may become discouraged about their capacity to attend and succeed in college, decreasing their aspirations. A lot of prior parental unemployment could instead be somewhat "inoculating," as the family adapts to more recurrent economic reversals. Growing financial problems in this context may convince some young people of the importance of attending and graduating from college.

\section{Table 5. First-difference Models for Educational Aspiration}

\begin{tabular}{|c|c|c|c|}
\hline Diff. in Educational Aspirations & 1 & 2 & 3 \\
\hline \multirow[t]{2}{*}{ Diff. log annual household income } & 0.029 & & \\
\hline & $(0.115)$ & & \\
\hline \multirow[t]{2}{*}{ Diff. additive financial problems index (AFPI) } & & 0.023 & 0.042 \\
\hline & & $(0.031)$ & $(0.041)$ \\
\hline \multirow[t]{2}{*}{ One month on average unemployment experience } & & & 0.103 \\
\hline & & & $(0.243)$ \\
\hline \multirow[t]{2}{*}{$>$ one month on average unemployment experience } & & & 0.213 \\
\hline & & & $(0.327)$ \\
\hline \multirow[t]{2}{*}{ One month on average unemployment exp. $\times$ Diff. AFPI } & & & $-0.158 *$ \\
\hline & & & $(0.062)$ \\
\hline \multirow[t]{2}{*}{$>$ one month on average unemployment exp. $\times$ Diff. AFPI } & & & 0.089 \\
\hline & & & $(0.075)$ \\
\hline \multirow[t]{2}{*}{ Constant } & 0.032 & 0.039 & 0.021 \\
\hline & $(0.139)$ & $(0.118)$ & $(0.153)$ \\
\hline $\mathrm{N}$ & 127 & 160 & 160 \\
\hline N-families & 97 & 124 & 124 \\
\hline R-square & 0 & 0.004 & 0.074 \\
\hline
\end{tabular}

${ }^{*} p<0.05,{ }^{* *} p<0.01, * * * p<0.001$ 


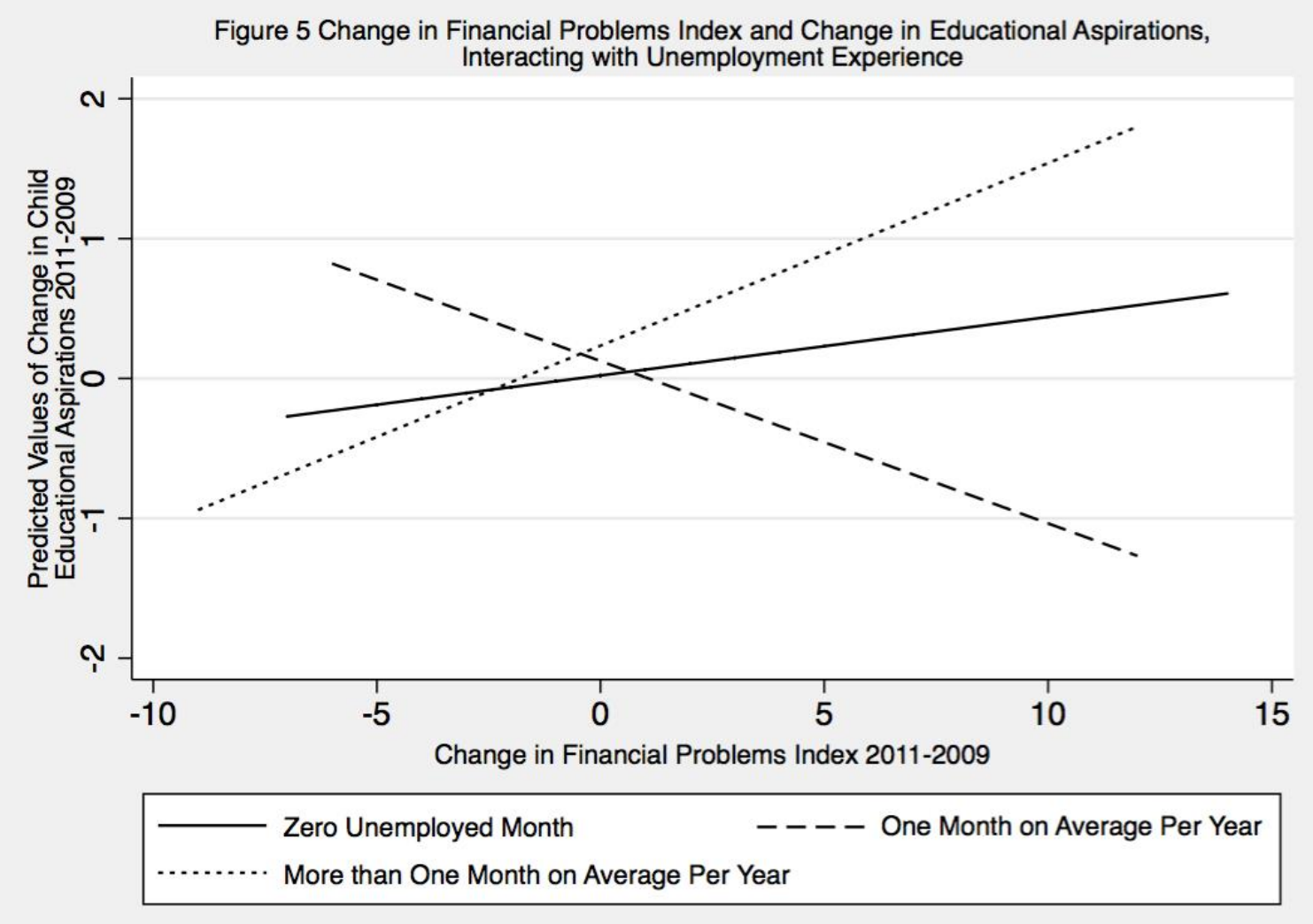

\section{Discussion}

In probing the consequences of parental hardship for children in the aftermath of the current Great Recession, we find evidence that parents' economic circumstances are reflected in children's achievement orientations. Interestingly, however, we found only one significant main effect. Of 8 main effects tests ( 2 hardship indicators, namely, log annual household income and the additive financial problems index $\times 2$ outcomes in the 2011 analyses; plus 2 hardship change indicators, that is, difference in log annual household income and difference in the additive financial problems index, $\times 2$ outcomes in the firstdifference analyses), we find just one to be statistically significant. Higher household incomes were associated with children's higher economic expectations in 2011 (Table 2 Model 2). Similarly, prior research (Mayer, 1997) found that household income does not matter very much for a range of child outcomes, although when measured over several years it had more predictive power. Schoon (this issue), also shows that household income has no significant effects on achievement orientations in final models for boys and girls. Levine's (2011) fixed effects analysis of data from the National Longitudinal Surveys of Youth found little evidence that parental employment status affected children's cognitive test scores. Interestingly, Elder (1974, p. 139, Table A-19, p. 312), in his study of the Oakland cohort - who experienced the aftermath of the economic collapse in their teen years - also reported that family economic loss during the Depression was not associated with lower occupational ambitions.

Altogether, we tested 40 interactions ( 2 economic status variables $X 5$ potential moderators $X 2$ outcomes $X 2$ modes of analysis), and found that just six (15 percent) were statistically significant. However, the pattern of moderation is more telling than the sheer number of significant interactions. We found evidence that the parental work history, the familial context of achievement, and the child's gender matter through their conditioning effects. Importantly, we found evidence that children in 
families who are more vulnerable by virtue of their parents' prior unemployment, react more strongly to their parents' contemporaneous economic circumstances. That is, the parents' history of unemployment appeared to sensitize children, such that their educational aspirations were more strongly affected by differences in household income and changes in parental financial strain. Differences in parental income had no significant effect on children's 2011 aspirations when their parents had no unemployment experience. But for those whose parents experienced unemployment, educational aspirations rose as household income increased (Figure 3). Similarly, the first-difference model for change in educational aspirations showed that children whose parents had experienced no unemployment did not significantly change their aspirations as their parents' financial strain increased; however, if parents' work histories included some unemployment (one month per year), increases in financial strain reduced children's aspirations (Figure 5).

We find that variables representing what we consider the educational achievement context of the family likewise condition the impacts of recent parental hardship. It should first be noted that parental economic expectations, measured during adolescence, have significant long-term effects on their adolescent children, though measurements of the parent and child generations are separated over a period of more than two decades. The main positive effect of parental economic expectation on children's expectation (Table 2), as well as its significant moderating effect, heightening the impact of change in household income on change in children's expectations (Figure 1), are unique findings of this study. High parental expectations, and a sense of efficacy upon which they are based, perhaps increase children's sensitivity to the effects of increasing (or decreasing) household income, affecting their anticipation of their own economic prospects. Furthermore, high parental aspirations, measured during adolescence, protected children from diminished educational aspirations when parents experienced financial problems (Figure 4). Apparently, those factors that enhance expectations and promote high aspirations during adolescence have long-term consequences, extending even to the next generation. This could be because parental economic expectations and educational aspirations are stable over time. Moreover, the more optimistic and ambitious parents may have higher expectations for their children and have relationships with their children that are of higher quality. Our future analyses will examine these possibilities.

Consistent with many studies, parental education was also associated with more positive achievement orientations among children (see also Schoon, this issue). When parents held BA degrees (or more), their children had significantly higher economic expectations (Table 2) and higher educational aspirations (Table 4) than children whose parents had only high school degrees (or less). Parental intermediate education, however, provided little incremental benefit (over the lowest educational origin category) for children's expectations or aspirations. The findings thus suggest that parents in this study had to obtain four-year college degrees to have a measurable impact on their children's orientations to the future.

Importantly, parental educational attainment moderated the effects of financial strain on children's economic expectations. When parents had only a high school education or less, their children's economic expectations declined from 2009 to 2011 as their parents' financial difficulties increased (Figure 2). We conclude that parents with higher levels of education may be able to buffer the effects of economic hardship on their children's expectations in difficult economic times; conversely, however, their children will not benefit as much when the family's financial prospects improve. Highly educated parents may encourage their children in ways that spill over to their children's confidence in a manner that is protective, irrespective of the immediate economic situation of the family. Financially strapped parents with the highest levels of education may be especially concerned that their children maintain high expectations for the future despite transient economic difficulties. In contrast, poorly educated parents appear to be the more vulnerable, as they are likely the most threatened by economic hardship. With the most limited prospects in the labor market, their opportunities to improve their families' economic positions may be the most constrained. Children who observe their parents' plight may 
become discouraged, lessening their confidence in the economic realm.

These findings suggest that to fully understand the implications of families' economic circumstances for children, we must take into account the families' level of vulnerability. Income differences and changes in financial strain have their strongest impacts among those children whose families' circumstances are the most precarious, as indicated by the parent's lack of post-secondary education and prior employment instability. When parents have low levels of education and when they have previously suffered unemployment, their children may face the greatest cumulative disadvantage in the face of immediate economic setbacks. Whereas the difficulties in the contemporary labor force experienced by individuals without post-secondary education are well recognized, this research indicates how such parental disadvantages may extend to their children. To the many good reasons for targeting interventions to these adults (in the form of assistance for further education and job training, supports for staying in school and achieving post-secondary degrees, and the general strengthening of the safety net), we add the possibility that such assistance could significantly heighten the aspirations and confidence of the next generation as their children look to their futures.

Reflecting gender differences in educational attainment, girls in this study had higher educational aspirations than boys. Interestingly, however, we observed no significant gender differences in economic expectations and only one significant interaction of the economic variables with gender: boys' educational aspirations were more responsive to parental financial problems than girls' (see Schoon, this issue). We also found that children's educational aspirations declined as they grew older.

Before proceeding further, a conceptual caveat is in order. A taken-for-granted assumption in our analyses, implicating parental income and financial stress for child achievement outcomes, is that these kinds of indicators of social stratification and hardship matter. This assumption is in accord with a long tradition of research in the United States that addresses the consequences of socio-economic status, indexed by education, income, and occupation, for style of life, values and other psychological orientations, mobility, and children's prospects. Interest in the effects of socio-economic inequality, especially of income, on children's educational achievement and life chances has become especially prominent in the aftermath of the Great Recession (Duncan and Murnane, 2011; Ermisch, Jantti, \& Smeeding, 2012). A quite different scholarly tradition, more prevalent in European circles (Bourdieu \& Passeron, 1990; Goldthorpe, Llewellyn, \& Payne, 1987; Willis, 1977) but also present in the United States (e.g., Wright, 1976), examines social class, not as continua of socioeconomic status indicators, but instead in terms of ownership and control over the means of production and the labor power of other workers. These approaches are not altogether distinct; they come together in attempts to address the overlapping character of social class and socio-economic statusrelated phenomena (Kohn, Naoi, Schoenbach, Schooler, \& Slomczynski, 1990; Goldthorpe, 1996; Wright \& Perrone, 1977). These alternative perspectives suggest the utility of extending studies of the impacts of the "Great Recession" on children by examining differences and changes in parents' relationship to the means of production, e.g., their employment status (employer, self-employed, employee), employment regulation (distinguishing the "working class" with labor contracts versus the "service class" of professional, managerial and administrative workers), supervisory responsibilities, manual vs. non-manual status, etc.

We should note that this research has additional limitations. The first is methodological. Our twopronged analytic strategy attempts to make the best use of our data, but each approach has advantages and drawbacks. The initial set of analyses of 2011 outcomes draws on a larger, more inclusive sample, but because other, unobserved variables might account for the significant coefficients, the findings are subject to alternative explanations. The firstdifference models have the advantage of being able to rule out some competing explanations (related to unobserved time stable differences), but at the cost of a smaller sample size. But while the patterns of findings across the two sets of analyses are not identical, they yield similar overall conclusions. First, they converge in documenting the absence of main, or additive, effects of contemporaneous (2011) and recent (change from 2009 to 2011) economic 
hardship in the family, on children's achievement orientations. Second, they each highlight interactions that suggest that children may be differentially vulnerable to their parents' economic difficulties, depending on prior parental unemployment and the familial context of educational achievement.

Furthermore, while our focus is on the effects of family economic well-being on children, we are observing the associations of the family economic indicators on children's achievement orientations approximately two and four years after the current "Great Recession" began. What we have found may characterize "recessionary times" but do not address the full impact of this historical event. We have no measures of children's orientations before the recession, so we cannot investigate change that may have been provoked by earlier "shocks" - reductions in family income and increases in financial strain at the beginning of the recession. We may have observed stronger effects if child data were obtained just a few years before (that is, in 2006 or 2007), before economic conditions deteriorated. Perhaps partly as a result, effect sizes reported in the tables $\left(R^{2}\right)$ are quite small. Relatedly, while we have observed parents' unemployment history for a long period of time prior to the recession (1997-2007), too few parents in this panel suffered unemployment in the years from 2008 to 2011 (37 parents) to render an analysis of its more recent effects meaningful. Moreover, small sample sizes in key subgroups mitigated against the detection of significant effects.

It should be noted that other factors, beyond the scope of this study, might also moderate the effects of economic hardship in the family of origin on children. For example, the school environment might promote high or low educational aspirations and expectations of the future, compensating for, or exacerbating, the effects of the home environment. Moreover, parents may lessen the consequences of diminishing family resources for their children by shifts in their spending - prioritizing the special needs of their children - and by maintaining high expectations for their children. In this particular set of analyses, we do not consider the effects of diminished quality of parent-child relationships that might accompany increases in financial strain, the extent to which children are aware of the economic hardships their families face, or children's evaluations of how well their families are coping with financial strain. Closer parent-child relationships and children's perceptions that the family is doing well, despite its difficulties, may surely buffer any depressing effects on children's aspirations and goals for the future. Moreover, as indicated by GrohSamberg and Voges' research (this issue), more affluent parents may significantly influence their children's economic well-being as they move into adulthood, heightening their standard of living and reducing the risk of poverty. Our future analyses will address these possibilities.

Finally, in this study we are addressing only the achievement domain of child well-being (see Crosnoe, this issue). The patterns we observe here may not hold for other outcomes, such as children's selfesteem, depressed mood, or behavioral problems. Walper and Silbereisen (1994) report, in their study of adolescents in Berlin and Warsaw, that parental education did not moderate the effects of economic loss on children's self-derogation and tendencies toward behavioral transgression. We plan to assess the effects of parental economic standing on mental health indicators and behavioral problems in our future research.

Despite these limitations, the linked lives of parents and children are clearly manifest in our findings. At a time of economic turmoil in the larger society, family economic hardships are reflected most strongly in the achievement orientations of children whose parents have the more unstable work histories, the more limited prior aspirations, and the more restricted educations. Perhaps differences and fluctuations in economic well-being in these families are more consequential because the parents do not have the human capital, the cultural and social capital, or the child rearing values and practices that would enable them to protect their children's achievement orientations from the detrimental effects of economic hardship. 


\section{Acknowledgements}

Earlier versions of this paper were presented at the 2012 Annual Meeting of the American Sociological Association, Denver, and the 2012 Meeting of the Society for Longitudinal and Life Course Studies, Paris. The Youth Development Study was supported by the Eunice Kennedy Shriver National Institute of Child Health \& Human Development (R01 HD044138) and by the National Institute of Mental Health (MH42843). The content is solely the responsibility of the authors and does not represent the views of the sponsors. The authors would like to thank Monica Johnson and Jeremy Staff for their critical reviews of an earlier version of the manuscript and their suggestions for improvement, as well as the anonymous reviewers.

\section{References}

Allison, P.D. (2009). Fixed Effects Regression Models. Los Angeles, CA: Sage.

Ashby, J.S., \& Schoon, I. (2010). Career success: The role of teenage career aspirations, ambition value and gender in predicting adult social status and earnings. Journal of Vocational Behavior, 77, 350-360. http://dx.doi.org/10.1016/i.jvb.2010.06.006

Bandura, A. (1977). Self-efficacy: Toward a unifying theory of behavioral change. Psychological Review, 84, 191225. http://dx.doi.org/10.1037/0033-295X.84.2.191

Bandura, A. (1982). The self and mechanisms of agency. In Suls, J. (Ed.) Psychological perspectives on the self. Vol. 1. (pp. 3-39). Hillsdale, New Jersey: Lawrence Erlbaum.

Bandura, A. (1997). Self-efficacy: The exercise of control. New York, NY: W.H. Freeman.

Beal, S.J., \& Crockett, L.J. (2010). Adolescents' occupational and educational aspirations and expectations: Links to high school activities and adult educational attainment. Developmental Psychology, 46, 258-265. http://dx.doi.org/10.1037/a0017416

Bourdieu, P. \& Passeron, J.C. (1990). Reproduction in Education, Society, and Culture. London: Sage.

Bronfenbrenner, U. (1979). The ecology of human development: Experiments by nature and design. Cambridge, MA: Harvard University Press.

Bureau of Labor Statistics (April 19, 2013a). Unemployment Rate Over-the-Year Change in Metropolitan Areas. Retrieved at: http://www.bls.gov/lau/lamtch08.htm on February 11, 2014.

Bureau of Labor Statistics (April 19, 2013b). Unemployment Rate Over-the-Year Change in Metropolitan Areas. Retrieved at: http://www.bls.gov/lau/lamtch10.htm on February 11, 2014.

Bureau of Labor Statistics (April 19, 2013c). Unemployment Rates for Metropolitan Areas. Retrieved at: http://www.bls.gov/lau/lamtrk11.htm on February 11, 2014

Conger, R.D., Ge, X., Elder, G.H., Lorenz, F O., \& Simons, R. (1994). Economic stress, coercive family process, and developmental problems of adolescents. Child Development, 65, 541-561. http://dx.doi.org/10.2307/1131401

Crosnoe, R. (2014). Youth, economic hardship, and the worldwide Great Recession. Longitudinal and Life Course Studies 5,199-204. http://dx.doi.org/10.14301/llcs.v5i2.296

Davies, M., \& Kandel, D.B. (1981). Parental and peer influences on adolescents' career plans: Some further evidence. American Journal of Sociology, 87, 363-387. http://dx.doi.org/10.1086/227462

Duncan, G.J. \& Murnane, R.J. (Eds.) (2011). Whither opportunity? Rising inequality, schools, and children's life chances. New York: Russell Sage Foundation.

Duncan, G.J., Brooks-Gunn, J., Yeung, W.J., \& Smith, J.R. (1998). How much does childhood poverty affect the life chances of children? American Sociological Review 63, 406-423. http://dx.doi.org/10.2307/2657556

Elder, G.H. (1974). Children of the great depression: Social change in life experience. Chicago, IL: University of Chicago Press.

Elder, G.H., Johnson, M., \& Crosnoe, R. (2003). The emergence and development of life course theory. In J.T. Mortimer \& M.J. Shanahan (Eds.), Handbook of the Life Course (pp. 3-19). New York, NY: Springer. http://dx.doi.org/10.1007/978-0-306-48247-2 1

Elder, G.H., \& Rockwell, R.C. (1979). Economic depression and postwar opportunity in men's lives: A study of life patterns and health. In R.G. Simmons (Ed.), Research in Community and Mental Health (Vol. 1, pp. 249-303). Greenwich, CT: JAI Press.

Elder, G. H., \& Shanahan, M. J. (2006). The life course and human development. In W. Damon and R. M. Lerner (Eds.), Handbook of child psychology: Theoretical models of human development (Vol. 1, 6th ed., pp. 665715). New York, NY: Wiley. 
Ermisch, J., Jantti, M., \& Smeeding, T. (Eds.) (2012). From Parents to children: The intergenerational transmission of advantage. New York: Russell Sage Foundation.

Farkas, G. (2011). Middle and high school skills, behaviors, attitudes, and curriculum enrollment, and their consequences. In G.J. Duncan \& R.J. Murname (Eds.) Whither opportunity? Rising inequality, schools, and children's life chances (pp.71-89). New York, NY: Russell Sage Foundation.

Froot, K.A. (1989). Consistent covariance matrix estimation with cross-sectional dependence and heteroskedasticity in financial data. Journal of Financial and Quantitative Analysis, 24, 333-355. http://dx.doi.org/10.2307/2330815

Goldthorpe, J.J. (1996). Class Analysis and the reorientation of class theory: The case of persisting differentials in educational attainment. British Journal of Sociology, 47, 481-505. http://dx.doi.org/10.2307/591365

Goldthorpe, J.H., Llewellyn, C., \& Payne, C. (1987). Social Mobility and Class Structure in Britain. Oxford: Clarendon Press.

Grabowski, L.S., Call, K.T., \& Mortimer, J.T. (2001). Global and economic self-efficacy in the educational attainment process. Social Psychology Quarterly, 64, 164-179. http://dx.doi.org/10.2307/3090131

Groh-Samberg, O., \& Voges, W. Precursors and consequences of youth poverty in Germany. Longitudinal and Life Course Studies 5, 151-172. http://dx.doi.org/10.14301/llcs.v5i2.281

Halpern-Felsher, B.L., Connell, J.P., Spencer, M.B., Aber, J.L., Duncan, G.J., Clifford, E., Crichlow, W.E., Usinger, P.A., Cole, S.P., Allen, L. \& Seidman, E. (1997). Neighborhood and family factors predicting educational risk and attainment in African American and White Children and Adolescents. In J. Brooks-Gunn, G.J. Duncan, \& J.L. Aber (Eds.) Neighborhood Poverty. Vol. 1 (146-173). New York: Russell Sage Foundation.

Hauser, R.M., Tsai, S.L., \& Sewell, W.H. (1983). A model of stratification with response error in social and psychological variables. Sociology of Education, 56, 20-46. http://dx.doi.org/10.2307/2112301

Heinz, W.R. (2014). Did the Great Recession affect young people's aspirations and reinforce social inequality? Longitudinal and Life Course Studies, XX,XXX-XXX.

Hitlin, S., \& Johnson, M.K. (2013). Reconceptualizing agency within the life course: The power of looking ahead. Paper presented at the Annual Meeting of the American Sociological Association, New York.

Hussemann, J.M., Mortimer, J.T., \& Zhang, L. (2011, August). Exploring the correlates of parental consent for child survey participation: An intergenerational longitudinal study. Paper presented at the Annual Meeting of the American Sociological Association, Las Vegas, NV.

Institute of Education Sciences. (2011). The condition of education: Table A-24-1 percentage of 25- to 29-year-olds who attained selected levels of education, by race/ethnicity and sex: Selected years, March 1975-2010 (Resource Document). Washington, DC: National Center for Education Statistics, U.S. Department of Education. Retrieved December 14, 2011, from http://nces.ed.gov/programs/coe/tables/table-eda-1.asp

Iversen, R.R., Napolitano, L., \& Furstenberg, F.F. (2011). Middle income families in the economic downturn: Challenges and management strategies over time. Longitudinal and Life Course Studies, 2, 286-300.

Retrieved October 12, 2012 from http://www.llcsjournal.org/index.php/llcs/article/view/150

Jacob, B.A., \& Linkow, T.W. (2011). Educational expectations and attainment. In G.J. Duncan \& R.J. Murname (Eds.) Whither opportunity? Rising inequality, schools, and children's life chances (pp. 133-162). New York, NY: Russell Sage Foundation.

Johnson, M.K., \& Mortimer, J.T. (2000). Work-family orientations and attainments in the early life course. In T.L. Parcel \& D.B. Cornfield (Eds.) Work and family: Research informing policy (pp. 215-248). Thousand Oaks, CA: Sage Publications.

Johnson, M.K., Oesterle, S. \& Mortimer, J.T. (2001). Adolescents' anticipations of work-family conflict in a changing societal context. In T.J. Owens \& S. Hofferth (Eds.) Children of the millennium: Where have we come from, where are we going? Advances in life course research (Vol. 6, pp. 233-261). Greenwich, CT: JAl.

Kainz, K., Willoughby, M.T., Vernon-Feagans, L., \& Burchinal, M.R. (2012). Modeling family economic conditions and young children's development in rural United States: Implications for poverty research. Journal of Family and Economic Issues 33, 410-420. http://dx.doi.org/10.1007/s10834-012-9287-2

Keister, L., \& Moller, S. (2000). Wealth inequality in the United States. Annual Review of Sociology, 26, 63-81. http://dx.doi.org/10.1146/annurev.soc.26.1.63

Kerckhoff, A.C. (1995). Social stratification and mobility processes: The interaction between individuals and social structures. In K. Cook, G. Fine, \& J. House (Eds.) Sociological perspectives on social psychology (pp. 476-496). New York, NY: Allyn Bacon.

Kohn, M.L. (1969). Class and conformity: A study in values. Homewood, IL: Dorsey. 
Kohn, M.L., \& Schooler, C. (1983). Work and personality: An inquiry into the impact of social stratification. Norwood, N.J.: Ablex Pub. Corp.

Kohn, M.L., Naoi, A., Schoenbach, C., Schooler, C., \& Slomczynski, K.M. (1990). Position in the class structure and psychological functioning in the United States, Japan, and Poland. American Journal of Sociology 95, 9641008. http://dx.doi.org/10.1086/229382

Lareau, A. (2002). Invisible inequality: Social class and childrearing in black and white families. American Sociological Review, 67, 747-776. http://dx.doi.org/10.2307/3088916

Lareau, A. (2003). Unequal childhoods: Class, race and family life. Berkeley: University of California Press.

Lee, J.C., \& Mortimer, J.T. (2009). Family socialization, economic self-efficacy, and the attainment of financial independence in early adulthood. Longitudinal and Life Course Studies, 1, 45-62. Retrieved October 12, 2012 from http://www.llcsjournal.org/index.php/llcs/article/view/28

Levine, P.B. (2011). How does parental unemployment affect children's educational performance? In G.J. Duncan \& R.J. Murname (Eds.) Whither opportunity? Rising inequality, schools, and children's life chances (pp. 315335). New York, NY: Russell Sage Foundation.

Mayer, S.E. (1997). What money can't buy: Family income and children's life chances. Cambridge, MA: Harvard University Press.

Mayer, S.E. (2001). How did the increase in economic inequality between 1970 and 1990 affect children's educational attainment? American Journal of Sociology, 107, 1-32. http://dx.doi.org/10.1086/323149

Mortimer, J.T. (1974). Patterns of intergenerational occupational movements: A smallest-space analysis. American Journal of Sociology, 79, 1278-1299. http://dx.doi.org/10.1086/225678

Mortimer, J.T. (1975). Occupational value socialization in business and professional families. Sociology of Work and Occupations, 2, 29-53. http://dx.doi.org/10.1177/073088847500200102

Mortimer, J.T. (1976). Social class, work and the family: Some implications of the father's occupation for familial relationships and sons' career decisions. Journal of Marriage and the Family, 38, 241-256. http://dx.doi.org/10.2307/350384

Mortimer, J.T. (1994). Individual differences as precursors of youth unemployment. In A.C. Petersen \& J.T. Mortimer (Eds.) Youth, unemployment, and society (pp. 172-198) Cambridge, MA: Cambridge University Press. http://dx.doi.org/10.1017/CBO9780511664021.011

Mortimer, J.T. (1996). Social psychological aspects of achievement. In A.C. Kerckhoff (Ed.) Generating social stratification: Toward a new generation of research (pp. 17-36). Boulder, CO: Westview Press.

Mortimer, J.T. (2003). Working and growing up in America. Cambridge, MA: Harvard University Press.

Mortimer, J.T., \& Kumka, D.S. (1982). A further examination of the 'occupational linkage' hypothesis. Sociological Quarterly, 23, 3-16. http://dx.doi.org/10.1111/i.1533-8525.1982.tb02216.x

National Bureau of Economic Research, September 6, 2013. U.S. Business Cycle Expansions and Contractions. www.nber.org/cycles.html Retrieved June 6, 2013.

Newman, K.S. (1988). Falling from grace: Downward mobility in the age of affluence. Berkeley: University of California Press.

Porfeli, E.J., \& Vondracek, F.W. (2007). Development of work values. In V.B. Skorikov \& W. Patton (Eds.) Career development in childhood and adolescence (pp. 105-126). Rotterdam, The Netherlands: Sense Publishers.

Prawitz, A.D., Kalkowski, J.C., \& Cohart, J. (2013). Responses to economic pressure by low-income families: financial distress and hopefulness. Journal of Family and Economic Issues, 34, 29-40. http://dx.doi.org/10.1007/s10834-012-9288-1

Reardon, S.F. (2011). The widening academic achievement gap between the rich and the poor: New evidence and possible explanations. In G.J. Duncan \& R.J. Murname (Eds.) Whither opportunity? Rising inequality, schools, and children's life chances (pp. 91-115). New York, NY: Russell Sage Foundation.

Reynolds, J.R., \& Johnson, M.K. (2011). Change in the stratification of educational expectations and their realization. Social Forces, 90, 85-109. http://dx.doi.org/10.1093/sf/90.1.85

Reynolds, J.R., Steward, M., MacDonald, R., \& Sischo, L. (2006). Have adolescents become too ambitious? High school seniors' educational and occupational plans, 1976 to 2000. Social Problems, 53, 186-206. http://dx.doi.org/10.1525/sp.2006.53.2.186

Rogers, W.H. (1993). Regression standard errors in clustered samples. Stata Technical Bulletin, 13, 19-23.

Ruggles, S., Alexander, J.T., Genadek, K., Goeken, R., Schroeder, M.B., and Sobek, M. (2010). Integrated public use microdata series: Version 5.0. [Machine readable database]. Minneapolis: University of Minnesota.

Rutter, M. (1970). Sex differences in children's response to family stress. In E.J. Anthony \& C. Koupernik (Eds.) The child in his family (pp. 165-196). New York, NY: Wiley. 
Ryu, S., \& Mortimer, J.T. (1996). The 'occupational linkage hypothesis' applied to occupational value formation in adolescence. In J.T. Mortimer \& M.D. Finch (Eds.) Adolescents, work, and family: An intergenerational developmental analysis (pp. 167-190). Newbury Park, CA: Sage.

Schoon, I. (2010). Planning for the future: Changing education expectations in three British cohorts. Historical Social Research, 35, 99-119. Retrieved October 12, 2012 from http://www.jstor.org/stable/20762452

Schoon, I. (2014). Parental worklessness and the experience of NEET among their offspring. Evidence from the Longitudinal Study of Young People in England (LSYPE). Longitudinal and Life Course Studies 5, 129-150. http://dx.doi.org/10.14301/llcs.v5i2.279

Schoon, I., Martin, P., \& Ross, A. (2007). Career transitions in times of social change: His and her story. Journal of Vocational Behavior, 70, 78-96. http://dx.doi.org/10.1016/j.jvb.2006.04.009

Schulenberg, J., Vondracek, F.W., \& Crouter, A.C. (1984). The influence of the family on vocational development. Journal of Marriage and the Family, 10, 129-143. http://dx.doi.org/10.2307/351871

Sewell, W.H., Haller, A.O., \& Ohlendorf, G.W. (1970). The educational and early occupational status attainment process: Replication and revision. American Sociological Review, 35, 1014-1027. http://dx.doi.org/10.2307/2093379

Sewell, W.H., Haller, A.O. \& Portes, A. (1969). The educational and early occupational attainment process. American Sociological Review, 34, 82-92. http://dx.doi.org/10.2307/2092789

Sewell, W.H. \& Hauser, R.M. (1975). Education, occupation, and earnings: Achievement in the early career. New York, NY: Academic Press.

Sewell, W.H., \& Hauser, R.M. (1976). Causes and consequences of higher education: Models of the status attainment process. In W.H. Sewell, R.M. Hauser, \& D. Featherman (Eds.) Schooling and Achievement in American Society (pp. 9-27). New York, NY: Academic Press.

Sewell, W.H., \& Hauser, R.M. (1980). The Wisconsin Longitudinal Study of social and psychological factors in aspirations and achievements. Research in Sociology of Education and Socialization, 1, 59-99. Retrieved October 12, 2012 from http://www.ssc.wisc.edu/wlsresearch/publications/files/ private/SewellHauser The.Wisconsin.Longitudinal.Study.of.Social.and.Psychological.Factors.in.Aspirations.and.Achieveme nts 1980.pdf

Sewell, W.H., \& Shah, V.P. (1968). Social class, parental encouragement, and educational aspirations. American Journal of Sociology, 73, 559-572. http://dx.doi.org/10.1086/224530

Shanahan, M., \& Mortimer, J.T. (1996). Understanding the positive consequences of psychosocial stress. In B. Markovsky, M. Lovaglia, \& R. Simon (Eds.) Advances in Group Processes (Vol. 13, pp. 189-209). Greenwich, CT: JAI Press.

Sribney, W. (2009). Comparison of standard errors for robust, cluster, and standard estimators. College Station, TX: StataCorp. Retrieved September 20, 2012, from http://www.stata.com/support/faqs/statistics/standarderrors-and-vce-cluster-option/

Stein, C., Hoffmann, E., Bonar, E., Leith, J., Abraham, K., Hamill, A., Kraus, S., Gumber, S., \& Fogo, W. (2013). The United States economic crisis: Young adults' reports of economic pressures, financial and religious coping and psychological well-being. Journal of Family and Economic Issues, 34, 200-210. http://dx.doi.org/10.1007/s10834-012-9328-x

U.S. Bureau of the Census. (2011). Income, expenditures, poverty and wealth: Table 703. Average earnings of yearround full-time workers by educational attainment: 2009. (Resource Document. Statistical Abstract of the United States) Washington, DC : U.S. Census Bureau. Retrieved December 14, 2011, from http://www.census.gov/compendia/statab/2012/tables/12s0703.pdf

Vondracek, F.W., Lerner, R.M., \& Schulenberg, J.E. (1986). Career development: A life-span developmental approach. Hillsdale, NJ: Lawrence Erlbaum.

Walper, S., \& Silbereisen, R.K. (1994). Economic hardship in Polish and German Families: Some Consequences for Adolescents. In R.K. Silbereisen \& E. Todt (Eds.) Adolescence in context: The interplay of family, school, peers and work in adjustment. (pp. 125-148). New York, NY: Springer-Verlag.

Williams, R.L. (2000). A note on robust variance estimation for cluster-correlated data. Biometrics, 56, 645-646. http://dx.doi.org/10.1111/j.0006-341X.2000.00645.x

Willis, P. (1977) Learning to Labor. How working class kids get working class jobs. Farnborough, UK: Saxon House. Wooldridge, J.M. (2002). Econometric analysis of cross section and panel data. Cambridge, MA: MIT Press.

Wright, E.O. (1976). Class boundaries in advanced capitalist societies. New Left Review, 98,3-41.

Wright, E.O, \& Perrone. L. (1977). Marxist class categories and income inequality. American Sociological Review, 42, 32-55. http://dx.doi.org/10.2307/2117730

Yeung, W.J. Linver, M.R., \& Brooks-Gunn, J. (2002). How money matters for young children's development: Parental investment and family processes. Child Development, 73, 1861-1879. http://dx.doi.org/10.1111/1467-8624.t01-1-00511 